\title{
EFEKTIVITAS PERMAINAN IMAJINASI TERHADAP PENGENALAN GEOMETRI ANAK USIA DINI KOBER SHIRATUN DHAUU'N CIPATAT BANDUNG BARAT
}

\author{
Eni Rohaeni ${ }^{1}$, Andrisyah ${ }^{2}$, \\ ${ }^{1}$ PG PAUD IKIP Siliwangi, Cimahi \\ 2 PG PAUD IKIP Siliwangi, Cimahi \\ rohaeni978@gmail.com, ${ }^{2}$ anisdeddy78@gmail.com
}

\begin{abstract}
The problem in the field is that they are not interested and children are not happy about learning in the classroom. Especially in learning to know geometric shapes. This is shown by not paying attention to the teacher who is explaining in front of the class. Almost all children are seen to be passive towards learning activities. In this study, researchers will explore the introduction of geometry at an early age of 5-6 years. The method in this study was carried out with a quasiexperimental with the data source being group B Kober Shiratun Dhauun children, amounting to 22 people, and divided into two groups. The results of the study prove that the imagination play method can arouse enthusiasm and increase understanding of geometry in children. It is seen that children are more enthusiastic and children become conducive atmosphere. From the data obtained on the $\mathrm{N}$ Gain results, the average value of experiment and control where the average value at the beginning of learning (pretest) of each class and at the end of learning (posttest) the average value of the experiment became 36.21 and control 28.64. Based on the results of the study, the introduction of geometry with the method of imagination play is more fun and interesting for children, so they are more motivated to study hard and passionately.
\end{abstract}

Keywords : Effectiveness, imagination play, geometry recognition

\begin{abstract}
Abstrak
Permasalahan di lapangan yakni kurang tertarik dan anak kurang senang terhadap pembelajaran di kelas. Terutama pada pembelajaran mengenal bentuk geometri. Hal tersebut ditunjukkan dengan tidak memperhatikan guru yang sedang menjelaskan di depan kelas. Hampir keseluruhan anak terlihat bersikap pasif terhadap kegiatan pembelajaran. Dalam penelitian ini, peneliti akan mengupas tentang pengenalan geometri pada usia dini 5-6 tahun. Metode dalam penelitian ini dilaksanakan dengan quasi eksperimen dengan sumber datanya adalah anak anak kelompok B Kober Shiratun Dhauun yang berjumlah 22 orang, dan dibagi menjadi dua kelompok. Hasil penelitian membuktikan ternyata metode permainan imajinasi dapat membangkitkan semangat dan meningkatkan pemahaman geometri pada anak. Hal ini terlihat anak lebih semangat dan anak menjadi suanana kondusif. Dari data yang diperoleh pada hasil $\mathrm{N}$ Gain yaitu rata-rata nilai eksperimen dan kontrol dimana nilai rata-rata pada awal pembelajaran (pretest) masing-masing kelas dan pada akhir pembelajaran (postest) nilai rata-rata eskperimen menjadi 36.21 dan kontrol 28.64. Berdasarkan hasil penelitian, pengenalan geometri dengan metode permainan imajinasi lebih menyenangkan dan menarik minat anak, sehingga lebih termotivasi untuk belajar dengan giat dan semangat.

Kata kunci: Efektivitas, permainan imajinasi, pengenalan geometri
\end{abstract}




\section{JURNAL GERIA}

ISSN : XXXX-XXXX (Print) XXXX-XXXX (Online)

\begin{tabular}{l|l|l} 
Vol.1 & No.1 Januari 2018 \\
\hline
\end{tabular}

PENDAHULUAN

Proses pembelajaran pada tahap anak usia dini adalah salah satu bentuk pendidikan yang berbasis tumbuh kembang anak. Adapun perkembangan anak terdap fisik dan motorik. Selain itu anak juga akan berkembang sesuai dengan kecerdasannya. Dalam perkembangannya hal ini sejalan dengan Undang-Undang Nomor 20 Tahun 2003 "Pendidikan AUD merupakan cara pengembangan anak-anak untuk menjadikan mereka sehat, cerdas, ceria dan sehingga bisa siap memasuki pendidikan SD". Salah satu pembelajaran yang bisa di berikan pada AUD yaitu tentang geometri

Perkembangan ini membangun perkembangan kognitif anak. Menurut Wells dalam Kusumaningrum (2015) kognitif adalah kemampuan menggunakan fikiran, mengingat suatu hal, menyelesaikan masalah, dan hal yang berhubungan dengan pengambilan keputusan, pengembangan kognitif berarti juga pengembangan matematika. Ada tahapan dalam pembelajaran matematika yaitu harus dari hal yang paling mudah hingga ke hal yang rumit. begitu juga pengenalan bentuk geometri, anak membedakan dari bentuk terkecil sampai bentuk terbesar, berbagai macam bentuk geomteri dari lingkaran, segitiga, persegi dan lain-lain.

Seorang pengajar TK dimana dalam proses pembelajaran tentu saja harus membuat rencana, membuat desain serta membuat sumber belajar sesuai dengan perkembangan kognitif siswa. Setiap anak berbeda tingkat perkembangan kognitifnya. Tentu saja guru seharusnya membuat perencanaan yang maksimal.

Kondisi nyata di lapangan, masih terdapat guru-guru TK yang melakukan pembelajaran yang biasa, dimana guru lebih dominan dibandingkan anak. Guru hanya sekedar menjelaskan tanpa anak terlibat langsung dalam pembelajaran. Hal ini terjadi di Kober Shiratun Dhauu'n pada kelompok B, proses pembelajaran mengenal bentuk geometri untuk proses perkembangan kognitif anak, berdasarkan observasi terlihat bahwa guru sebatas mengajarkan bentuk geomteri berdasarkan gambar saja. Guru mengenalkan secara visual saja bentuk-bentuk geomteri tersebut.

Di dalam kelas guru hanya mengenalkan dan menyebutkan nama-nama bentuk geometri berdasarkan gambar yang diperlihatkan kepada anak, selanjutnya anak hanya menjawab dari pertanyaan guru tersebut, dilakukan dengan pengulangan. Hal tersebut memang benar anak menjadi hafal nama-nama bentuk geometri namun anak tersebut tidak mengalami proses secara langsung (nyata) dalam pembelajarannya. Hal tesebut sejalan dengan pengenalan bentuk geometri yang merupakan strategi sebagai anak berlatih seperti yang diungkapkan Novelandari (2016) bahwa kemampuan merupakan daya untuk melakukan suatu tindakan sebagai hasil dari pembawaan dan latihan. Anak pada usia 5-6 tahun tentu saja memiliki daya ingat yaitu + 10 menit, pada durasi waktu tersebut, anak tidak mau diam bahkan anak kurang betah di dalam kelas. Hal tersebut disebabkan pembelajaran ini 


\section{JURNAL GERIA}

ISSN : XXXX-XXXX (Print) XXXX-XXXX (Online)

\begin{tabular}{l|l|l} 
Vol.1 & No.1 Januari 2018 \\
\hline
\end{tabular}

monoton. Biasanya yang terjadi anak mengalihkan perhatian ke guru mengerjakan hal-hal yang lainnya. Berdasarkan hasil pengamatan pada kelompok B di kober shiratuun dhauun permasalahan yang menyangkut aktivitas anak dalam mengenal bentuk geomteri, dapat dilihat dari kebanyakan anak yang kurang tertarik dan bahkan tidak senang dalam pembelajaran. Hal tersebut ditunjukkan dengan tidak memperhatikan guru yang sedang menjelaskan di depan kelas. Kebanyakan anak terlihat bersifat pasif terhadap kegiatan pembelajaran. Aktivitas ketika anak yang tidak tertarik pada pembelajaran itu yaitu kebanyakan anak masih belum dapat menunjukan bentuk-bentuk geometri serta memberikan contoh benda benda dengan bentuk tertentu misalnya lingkaran, segitiga, dan kotak.

Kegiatan di Kober Shiratun Dhauun sebagian besar menerapkan konsep bermain sambil belajar, belajar seraya bermain. Adapun media yang digunakan adalah buku paket pelajaran maupun media lainnya sudah cukup digunakan. Kegiatan bermain yang berkaitan dengan kemampuan kognitif anak khususnya kemampuan matematika yang dilaksanakan yaitu permainan balok, kartu angka, kartu huruf, mengelompokkan benda. Kegiatan pembelajaran melalui media-media disebutkan di atas sudah pernah dilakukan semuanya, dan anak terlihat sudah bosan dengan benda dan peralatan tersebut. Suyanto (2005) menyatakan semua anak memiliki pola perkembangan kognitif yang sama yaitu melalui empat tahapan yaitu : sensori-motor, properasional, konkret-operasional, dan formal-operasional.
Anak TK termasuk pada kategori perkembangan pra operasional. Anak sudah mulai mampu berpikir konkrit, mengenal simbol-simbol, bentuk dan lain-lain. Dalam mencapai tujuan yang optimal dalam mengenal bentuk-bentuk geometri diperlukan media yang sesuai dengan karakteristik anak. Eliyawati (2005) karakteristik anak usia dini dengan daya perhatian, untuk menarik perhatian tersebut maka dikenalkan bentuk-bentuk geometri. Geometri menurut Nidho (2013) adalah mengidentifikasi bentuk-bentuk, mengamati bangunan dan memisahkan gambar-gambar misalnya lingkaran, segitiga, segiempat dan lain-lain. Untuk itulah efektivitas permainan imajinasi diperlukan pada anak melalui pengenalan media geometri.

\section{METODE}

Penelitian ini merupakan penelitian eksperimen. Sugiyono (2014) menjelaskan bahwa penelitian eksperimen yaitu penelitian mencari pengaruh, perlakuan tertentu terhadap yang lain. Pengambilan sampel dilakukan dengan sampel bertujuan didasarkan peneliti ingin mendapatkan hasil yang akurat terhadap penelitian ini.

Adapun jenis design yaitu yang dipilih dalam penelitian ini yaitu nonequivalent control group. Desain ini didasarkan karena adanya dua kelompok yang tidak dipilih secara acak, yaitu kelompok eksperimen dan kelompok kontrol. Menurut Sugiyono (2008:67), Hal yang paling penting untuk melihat sejauh mana kemampuan anak sebelum dan sesudah pembelajaran adalah dengan pengumpulan 


\section{JURNAL GERIA}

ISSN : XXXX-XXXX (Print) XXXX-XXXX (Online)

\begin{tabular}{l|l|l} 
Vol.1 & No.1 Januari 2018 \\
\hline
\end{tabular}

informasi mengenai perkembangan

anak, oleh karena itu penelitian ini diawali dengan observasi di kelas baik eksperimen maupun kontrol dan dokumentasi.

\section{HASIL DAN PEMBAHASAN}

\section{Hasil}

Tahapan perkembangan anak yaitu : sensori-motor, properasional, konkret-operasional, dan formaloperasional. Anak TK termasuk pada kategori perkembangan pra operasional. Anak sudah mulai mampu berpikir konkrit, mengenal simbol-simbol, bentuk dan lain-lain. Dalam mencapai tujuan yang optimal dalam mengenal bentuk-bentuk geometri diperlukan media yang sesuai dengan karakteristik anak. Eliyawati (2005) karakteristik anak usia dini dengan daya perhatian, untuk menarik perhatian tersebut maka dikenalkan bentuk-bentuk geometri. Geometri menurut Nidho (2013) adalah mengidentifikasi bentuk-bentuk, mengamati bangunan dan memisahkan gambar-gambar misalnya lingkaran, segitiga, segiempat dan lain-lain. Untuk itulah efektivitas permainan imajinasi diperlukan pada anak melalui pengenalan media geometri.

\section{METODE PENELITIAN}

Penelitian ini merupakan penelitian eksperimen. Sugiyono (2014) menjelaskan bahwa penelitian eksperimen yaitu penelitian mencari pengaruh, perlakuan tertentu terhadap yang lain. Pengambilan sampel dilakukan dengan sampel bertujuan didasarkan peneliti ingin mendapatkan hasil yang akurat terhadap penelitian ini.

Adapun jenis design yaitu yang dipilih dalam penelitian ini yaitu nonequivalent control group. Desain ini didasarkan karena adanya dua kelompok yang tidak dipilih secara acak, yaitu kelompok eksperimen dan kelompok kontrol.

\section{HASIL DAN PEMBAHASAN}

\section{HASIL}

Data-data yang diperoleh dari hasil penelitian yang telah dilakukan selama delapan kali pertemuan yang terdiri dari satu kali pretes, 8 kali perlakuan pembelajaran dan satu kali postes. Berikut adalah hasilnya :

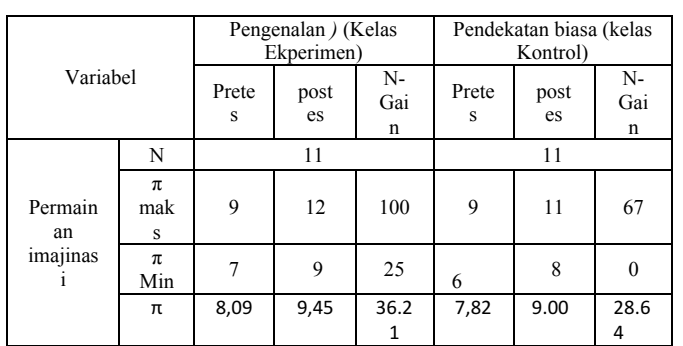

Nilai Rata-rata tersebut jika kita sesuaikan dengan kriteria perhitungan $\mathrm{N}$ gain maka Kelas eksperimen memiliki interprestasi sedang yang artinya pengenalan geometri memiliki keefektifan yang rendah dalam meningkatkan permainan imajinasi anak, sedangkan kelas kontrol yang memiliki interprestasi rendah juga berarti pembelajaran klasikal memiliki keefektifan yang rendah untuk meningkatkan permainan imajinasi anak usia dini.

Berikut adalah gambarannya : 


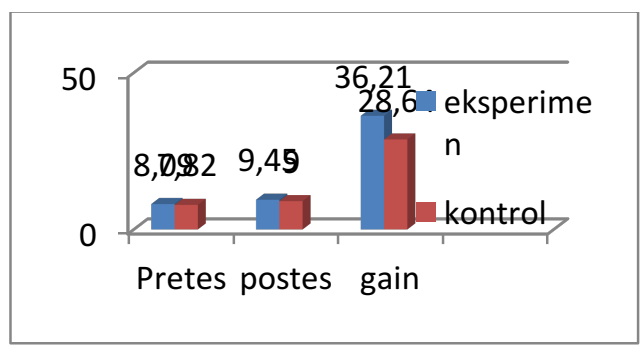

Gambar 1. Nilai N Gain

\section{Pembahasan}

1. Pengenalan geometri setelah dilakukan penelitian

Perkembangan kognitif pada anak-anak di kelas kontrol dan kelas eksperimen sebetulnya sama-sama memiliki keefektifan yang baik untuk meningkatkan perkembangan kognitif, hal ini terbukti dari hasil perhitungan nilai $\mathrm{N}$ Gain yang di hasilkan. hanya saja pembelajaran dengan permainan imajinasi memiliki tingkat keefektifan lebih besar dibandingkan dengan pembelajaran klasikal. dari pengamatan yang dilakukan keadaan kelas yang klasikal untuk usia 5-6 tahun memang terbilang kondusif dan lebih tenang dibanding dengan kegiatan kelas yang menggunakan permainan imajinasi yang dirasakan ramai bahkan jika guru tidak memiliki strategi khusus maka kelas akan menjadi ribut. akan tetapi dari keramaian kelas pada pembelajaran permainan imajinasi menjadikan kondisi anak lebih bersemangat, lebih antusias dibandingkan dengan pembelajaran klasikal karena ada permainanya maka anak seakan-akan harus bersaing untuk mendapatkan nilai terbaik agar menjadi pemenangnya. dari penelitian yang sudah di lakukan ternyata anak lebih suka dengan keadaan kelas yang ramai, penuh persaingan tetapi persaingan yang bersifat kelompok bukan persaingan secara pribadi.

\section{KESIMPULAN}

Dari perhitungan tersebut jadi :

1. Kemampuan guru melaksanakan proses belajar mengajar

a. Guru harus memberikan contoh sebuah karya nyata kepada anak. Hal ini disebabkan untuk membangun ide dan kreativitas anak.

b. Pemberian reward berupa pujian dan motivasi dapat membuat anak lebih termotivasi dalam mengikuti kegiatan pembelajaran.

2. Kreativitas anak dalam permainan konstuktif

a. Kreativitas anak dapat berkembang dengan baik bila didukung oleh beberapa faktor yaitu memberikan rangasangan mental yang baik menciptakan lingkungan yang kondusif, peran guru dalam mengembangkan kreativitas.

b. Anak cenderung melihat hasil temannya dalam membuat suatu bentuk.

\section{REFERENSI}

Depdiknas.(2003). Undang-undang RI No. 20 Thn 2003. Tentang Sistem Pendidikan Nasional.

Eliyawati, Cucu. (2005). Pemilihan dan Pengembangan Sumber Pembinaan Pendidikan

Izzanty Rita Eka. (2005). Mengenali Permasalahan

Perkembangan Anak Usia Tk. Jakarta : Departemen Pendidikan Nasional.

Juwita. 2010. Perkembangan fisik motorik dan bahasa Surakarta. UMS 


\section{JURMAL GERIA}

ISSN : XXXX-XXXX (Print) XXXX-XXXX (Online)

\begin{tabular}{l|l|l} 
Vol.1 & No.1 Januari 2018 \\
\hline
\end{tabular}

Kusumaningrum, E.

Fajri.

Chumdari, Mahmud Hasan.

(2015). Upaya Peningkatan

Pengenalan Bentuk

Geomteri Melalui

Penggunaan Media Papan

Flanel Pada Anak

KelompomA TK Al

Mukhlisin Karanganyar

Tahun Ajaran 2014/2015.

https://jurnal.fkip.uns.ac.id/i

ndex.php/paud/article/viewF

ile/6094/4216.

$[15$

September 2019].

Nidho, Fuadillah. 2013 "Upaya

Meningkatkan Pengenalan

Geometri dengan Puzzle

Bervariasai pada Kelompok

B TK Al-hikmah Pemalang,

Semarang."

Novelandari, Ika., Simatupang

Dorlina. (2016).

Meningkatkan Kemampuan

Mengenal Bentuk Geometri

Melalui Kegiatan Mozaik

Pada Kelompok A.

https://jurnalmahasiswa.une

sa.ac.id/index.php/paud-

teratai/article/download/142

$77 / 4905$.

Sugiyono. (2014). Metode Penelitian Pendidikan Pendekatan Kuantitatif Kualitatif, dan $R \& D$. Bandung: Alpabet.

Slamet Suyanto. (2005). Konsep Dasar Anak Usia Dini. Jakarta: Departemen Pendidikan Nasional. 


\section{JURNAL GERIA}

ISSN : XXXX-XXXX (Print) XXXX-XXXX (Online)

\begin{tabular}{l|l|l} 
Vol.1 & No.1 & Januari 2018 \\
\hline
\end{tabular} 